\title{
Endometriosis of colon as a cause mimicking Crohn's disease: a potential pitfall in diagnosis
}

\section{Endometrioza jelita grubego naśladująca chorobę Leśniowskiego-Crohna - potencjalny problem diagnostyczny}

\author{
Jacek Śmigielski ${ }^{1}$, Beata Woźniak ${ }^{2}$, Marian Brocki ${ }^{1}$ \\ ${ }^{1}$ Department of Thorax, General and Oncological Surgery, Medical University of Lodz, Poland; \\ Head of Department: Prof. Marian Brocki MD, PhD \\ 2Department of Endoscopy, EndoTerapia, Lodz, Poland
}

Przegląd Menopauzalny 2013; 2: 163-165

\section{Summary}

Endometriosis is a common condition in many women of the child-bearing age. It affects approximately $8-15 \%$ of the menstruating female population. Usually endometriosis can be found in the peritoneal cavity. Ectopic foci can be located in a number of other organs, such as the lung, gall bladder, retroperitoneal space, stomach, small and large intestine and pancreas. It is found beyond the peritoneal cavity in $0.2 \%$ of the population. Endometriotic foci in the colon have already been discussed, however, there is a rare type of this condition that imitates Crohn's disease. This paper presents a long-term disease which was diagnosed and treated as Crohn's disease. In the third year of treatment, colonic endometriosis was diagnosed correctly.

Key words: endometriosis, Crohn's disease, colon.

\section{Streszczenie}

Opisywany w niniejszej pracy przypadek jest o tyle ciekawy, że kolejne badania pacjentki przez 3 kolejne lata diagnostyki nie dały ostatecznego rozpoznania. Ze względu na postawioną przed 3 laty diagnozę - choroba Leśniowskiego-Crohna - pacjentkę leczono błędnie. Trudności w rozpoznaniu tej jednostki chorobowej stale występują. Endometrioza to częsta przypadłość wielu kobiet w wieku rozrodczym. Choroba dotyczy przede wszystkim kobiet, ale znane są przypadki endometriozy u mężczyzn z rakiem gruczołu krokowego. U kobiet występuje u ok. 8-15\% miesiączkującej populacji. Najczęstszym umiejscowieniem zmian jest jama otrzewnej. W wielu innych narządach, takich jak płuco, pęcherzyk żółciowy, przestrzeń zaotrzewnowa, żołądek, jelito cienkie i grube oraz trzustka, można rozpoznać ogniska ektopowe. Umiejscowienie poza jamą otrzewnej dotyczy wg danych z piśmiennictwa 0,2\% populacji. Ogniska endometriozy w jelicie grubym już opisywano, ale rzadkością jest postać choroby, która imituje chorobę Leśniowskiego-Crohna. W pracy opisano pacjentkę z wieloletnią chorobą zdiagnozowaną i leczoną jako choroba Leśniowskiego-Crohna, u której dopiero po kilku latach leczenia rozpoznano prawidłowo endometriozę jelita grubego. Po prawidłowo przeprowadzonym procesie diagnostycznym leczeniem z wyboru jelitowej postaci endometriozy jest laparoskopowa resekcja jelita. Jest to technika ogólnie dostępna, obarczona niewielką liczbą powikłań. Ostatnio ukazało się kilka prac na temat resekcji jelita ze wspomaganiem robota.

Słowa kluczowe: endometrioza, choroba Leśniowskiego-Crohna, okrężnica.

\section{Introduction}

Endometriosis is a common condition in many women of child-bearing age. Its most common site is the peritoneal cavity. Endometriotic foci can also be found in many other organs, such as the lung, urinary bladder, retroperi- toneal space and alimentary tract [1-7]. However, the colon is the most common ectopic focus. Colonic endometriosis has already been described but there is still a rare type of this condition that imitates Crohn's disease. This work presents the case of a long-term disease that was first di- 
agnosed and treated as Crohn's disease. In the third year of observation, diagnostics and treatment, the disease was recognised properly as colonic endometriosis.

\section{Case report}

A 50-year-old woman presented in hospital for surgery due to polypoid changes in the colon within 20-30 $\mathrm{cm}$ from the edge of the anus. For a few years, the patient had complained of the pain in the abdomen with concurrent diarrhoea and transient bleeding from the colon. Previously, the patient was diagnosed (ultrasound, CT scan - NAD) and underwent colonoscopy with a histopathological examination (result no. 100165823/26.02.2009Morbus Crohn). The patient was treated for colitis for approximately 3 years. The medication prescribed through that period comprised mesalasine, corticosteride and iron preparations. After about a year, another sample for histopathological investigation was collected during a routine examination on 08.10.2010 (Fig. 1). The result, no. 100314786/14.10.2010, was ambiguous - the mucosa with a slight dysplasia in the enlarged glands. Numerous branching capillaries were found in the lamina propria,

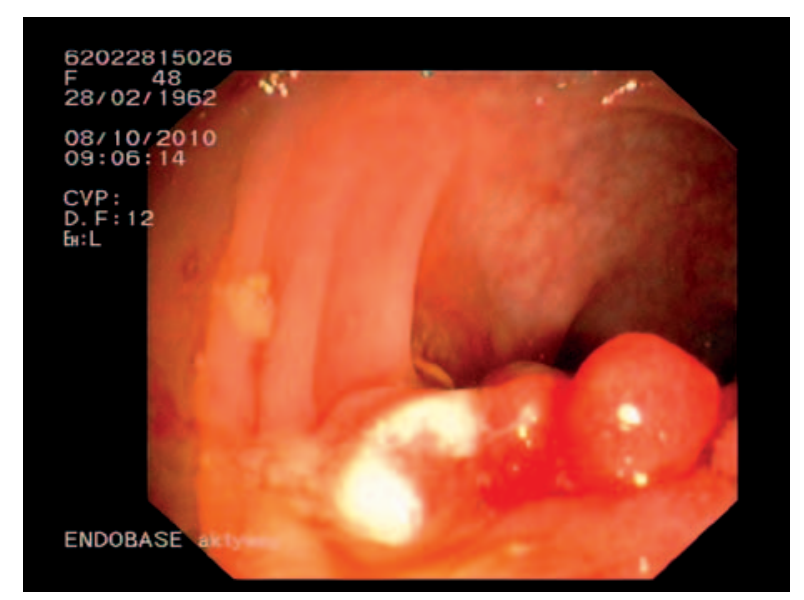

Fig. 1. View of colonoscopy from 08.10.2010

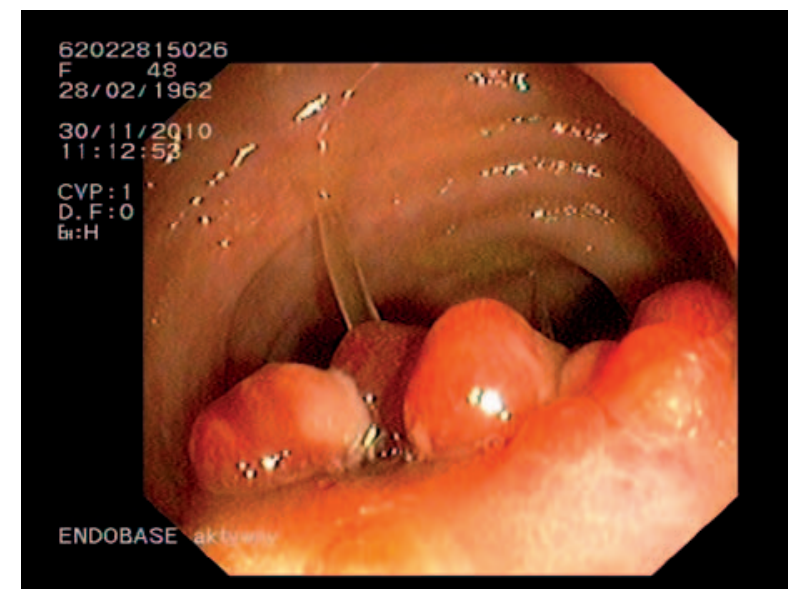

Fig. 2. View of colonoscopy from 30.11.2010 effusions and an inflammatory infiltration of granulocytes and lymphocytes, as well as oedema. No final diagnosis was reported. The patient was still treated for an inflammatory bowel disease (IBD). Another endoscopy was performed on 30.11.2010 (Fig. 2). Histopathological result no. 3677/2010/KOL showed a slight oedema of the mucosa and focal fibrosis of the lamina propria, as well as a granulocytic infiltration with a crypt abscess.

\section{Results}

The material could not be qualified to differentiate between an inflammation, adenoma, and secondary lesions or dysplasia. The patient was still treated for Crohn's disease. The pain did not subside, the medicaments were continuously prescribed. The next histopathological examination, no. 100429689/23/01/2012, was conducted on 13.01 .2012 (Fig. 3) and revealed the mucosa and submucosa of the colon with endometriotic foci, which were mainly located within the submucosa. Estrogen receptors (+), CD10 (+), CK7 (+) and CK20 (-) were found. The patient was referred for a surgical procedure at the local department.

On admission, her vital signs and physical examination were normal. The laboratory studies were as follows: WBC (white blood cells) $11160 / \mathrm{mm}^{3}$, Hb (hemoglobin) $12.8 \mathrm{~g} / \mathrm{dl}$, platelets $339000 / \mathrm{mm}^{3}$, AST (aspartate transaminase) $20 \mathrm{IU} / \mathrm{l}$, ALT (alanine transaminase) $11 \mathrm{IU} / \mathrm{l}$, alkaline phosphatase $68 \mathrm{IU} / \mathrm{l}$, total bilirubin $0.48 \mathrm{mg} / \mathrm{dl}$, total protein $6.9 \mathrm{~g} / \mathrm{dl}$, albumin $3.5 \mathrm{~g} / \mathrm{dl}$, CRP (C-reactive protein) $18.0 \mathrm{mg} / \mathrm{dl}$, and prothrombin time of 13.4 seconds. The viral marker tests, including HBsAg, anti-HBsAb and anti-HCV, were all negative. The patient underwent a laparoscopic resection of the portion of the colon. No postoperative complications were noticed. Two days following the operation, the patient was released from hospital for further monitoring at surgical and gynaecological clinics.

The patient's further recovery was uneventful.

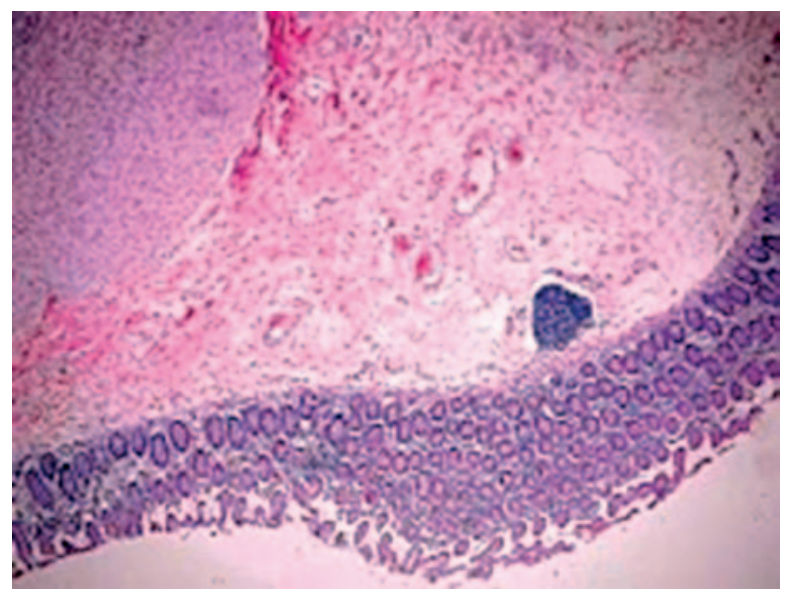

Fig. 3. Mucosal inflammation from 08.10.2012 


\section{Discussion}

Endometriosis was first described by Shroen in 1690, yet its signs and symptoms were discussed not earlier than in 1769 by Duff. Endometriosis is defined as an atypical hyperplasia endometrium outside the uterine cavity [8]. Mainly, the disease affects women, however, there have been some cases of endometriosis in men with prostate cancer [9]. The disease can be found throughout the length of both the small and large intestines $[2-4,10]$.

A clinical examination and interview are crucial in the diagnostics. In addition, ultrasound or CT scan of the abdomen are performed. With the development of modern techniques, endoscopic ultrasound and EUS guided FNA are used in the diagnostics of the lesions located in the lower part of the colon [11]. In some cases, Multislice CT enteroclysis is used [12]. A proper diagnostic process is followed by a laparoscopic resection of the colon, which is a method of choice in colonic endometriosis [13]. This technique is widely available and not encumbered with many complications. Recently, the results of several studies have been published on the use of robotic surgery and robotic assisted surgery [14]. Although these techniques merely support the classical laparoscopy, their results are very promising.

The presented case is interesting insofar that the 3-year diagnostics could not provide a final diagnosis. Throughout the 3 -year-long diagnostic process (Crohn's disease) the patient was subject to inappropriate treatment. There are many descriptions in the literature of forms of endometriosis that simulate other diseases. Either through its symptoms and signs or its clinical picture, endometriosis can imitate other diseases with similar signs and symptoms. Samet et al. [15] discuss colonic endometriosis, which perfectly imitates colon cancer: the lesion was not found to differ from the cancer under virtual endoscopy. Another example of imitation can be seen in another case opposite to the one described here. Teke et al. [16] presented the case of a young woman with Crohn's disease situated in the colon, with concurrent polyps that narrowed the intestine and a regular monthly rectal haemorrhage. In endoscopy, the picture showed endometriosis in this part of the colon. The patient was subject to hemicolectomy. The postoperative histopathological examination excluded the preliminary diagnosis and confirmed Crohn's disease.

Difficulties in diagnosing this disease entity are still present, yet now they are not so often, possibly due to more detailed diagnostics and histopathological examinations: a good example of this is the case presented within this study. The ultrasound and CT scans did not reveal any lesions. The picture revealed by endoscopy was similar to the picture of a different bowel inflammation. Often histopathology did not provide any firm evidence. Detailed receptor tests facilitated a correct diagnosis.

All in all, the diagnosis of endometriosis can cause a tremendous difficulty even to an experienced endoscopist, gynaecologist, surgeon or pathologist. The diagnostic process can be long while an individually conducted examination may not provide an unequivocal diagnosis. In each dubious case every possible diagnostic method, including a repetitive microscopic examination and surgery, should be incorporated.

\section{References}

1. Fang HY, Jan Cl, Chen CK, et al. Catamenial pneumothorax due to bilateral pulmonary endometriosis. Respir Care 2012; 57: 1182-5.

2. Pisanu A, Deplano D, Angioni S, et al. Rectal perforation from endometriosis in pregnancy: Case report and literature review. World J Gastroenterol 2010; 16: 648-51.

3. Cirillo F, Vismarra M, Buononato M, et al. Endometriosis of the caecum and ileo-caecal valve. A case report and review of the literature. Chir Ital 2008; 60: 603-6

4. Garg NK, Bagul NB, Doughan S, et al. Intestinal endometriosis - a rare cause of colonic perforation. World J Gastroenterol 2009; 15: 612-4.

5. Kashyap P, Medeiros F, Levy M, Larson M. Unusual submucosal tumor in the stomach. Diagnosis: Endometriosis. Gastroenterology 2011; 140: e7-8.

6. Monrad-Hansen PW, Buanes T, Young VS, et al. Endometriosis of the pancreas. J Minim Invasive Gynecol 2012; 19: 521-3.

7. González-Longoria G, Mejía-Ovalle R, Salinas-Aragón E, et al. Perineal endometriosis with anal external sphincter involvement: a case-report. Rev Gastroenterol Mex 2011; 76: 173-7.

8. Evers JL. Endometriosis does not exist; all women have endometriosis. Hum Reprod 1994; 9: 2206-9.

9. Martin JD, Hauck AE. Endometriosis in the male. Am Surg 1985; 7: 426-30. 10. Arévalo Suárez FA, Cerrillo Sánchez G. Appendicular endometriosis as a finding in cases of acute appendicitis. 4 case reports. May 2 nd national hospital. Rev Gastroenterol Peru 2006; 26: 324-7.

11. Leyden J, Winter DC, Clarke E, O'Keane C. Endoscopic ultrasound and EUS-guided FNA in the diagnosis of rectal endometriosis. Ir Med J 2009; 102: 301.

12. Biscaldi E, Ferrero S, Fulcheri E, et al. Multislice CT enteroclysis in the diagnosis of bowel endometriosis. Eur Radiol 2007; 17: 211-9.

13. Campagnacci R, Perretta S, Guerrieri M, et al. Laparoscopic colorectal resection for endometriosis. Surg Endosc 2005; 19: 662-4.

14. Daraï E, Ballester M, Chereau E, et al. Laparoscopic versus laparotomic radical en bloc hysterectomy and colorectal resection for endometriosis. Surg Endosc 2010; 24: 3060-7.

15. Samet JD, Horton KM, Fishman EK, et al. Colonic endometriosis mimicking colon cancer on a virtual colonoscopy study: a potential pitfall in diagnosis. Case Report Med 2009; 2009: 379578.

16. Teke Z, Aytekin FO, Atalay AO, et al. Crohn's disease complicated by multiple stenoses and internal fistulas clinically mimicking small bowel endometriosis. World J Gastroenterol 2008; 14: 146-51. 